societies that do not want to significantly alter the terms of colonial domination

The problem stems from D'Arcy's reliance on 'hypothetical reasoning' - where idealized scenarios are posited and the author works through the scenario in order to produce analytical arguments and principles. These theories are then applied to empirical cases without delving into a rich contextual analysis of the situation. D'Arcy's truncated descriptions of case studies can then leave out the role of racist or patriarchal publics and confine the problem to 'intransigent elites.' D'Arcy's reliance on idealised scenarios greatly hinders his ability to shed new light on how oppressive power circulates by delving into rich contextual analysis of past cases where militant protest has occurred.

D'Arcy's reliance on hypothetical reasoning also prevents him from fully engaging with 'non-violent realists' like Taiaiake Alfred and Gandhi. D'Arcy briefly mentions that Alfred has a "firm preference for "nonviolent contention" (59) and asserts Gandhi and King "attached great moral importance to nonviolence" (77). But for Alfred and Gandhi, advocating for non-violence is based on a means-ends calculation that assumes violent means of social transformation will impair the ability of societies to manifest non-violent ends.

D'Arcy is right in challenging the view that militant protest is an impediment to dialogue, institutional procedure, 'law and order' and other forms of democratic decision-making. Yet, the author's focus on normative standards and hypothetical reasoning prevents him from addressing other important questions. Namely, why do so many people in democratic societies view militant protest as anti-democratic, and how do we proliferate these practices in a way that contributes to just societies?

Matthew Wildcat

University of British Columbia

\title{
Vivienne Poy, Passage to Promise Land: Voices of Chinese Immigrant Women to Canada (Kingston: McGill-Queen's University Press, 2014). 288 pp. \$39.95 Paperback.
}

In Passage to Promise Land, Vivienne Poy confronts challenges on two different but related fronts: not having a conventional base of primary source materials, and having a close personal connection with the subject at hand. Neither challenge is insurmountable. Many scholars have addressed these potential obstacles by expanding the traditional definition of sources, bringing self-awareness to their subjectivity, and questioning assumptions around primary sources and academic objectivity in the first place. One might also argue that these problems are not problems at all. Rather, they are an opportunity to apply creativity and fresh 
perspectives to longstanding themes within historical scholarship.

Poy's work offers just such an opportunity. This book traces the history of Chinese women's immigration to and settlement in Canada over the second half of the twentieth century. The author interviewed twenty-eight Chinese women who arrived from China and Hong Kong during this period, and places their stories against the backdrop of larger immigration trends, transnational histories, and local socio-political-economic patterns. The book quotes extensively from these oral histories, allowing the women's voices to emerge clearly from the thicket of contextual information. Using the intensely personal to illuminate the national, transnational, and universal, Poy shows how individuals navigated the turbulence of war, barriers to migration, and gender and racial discrimination.

The author's own voice is informed by her experience as an active and accomplished member of the Chinese Canadian community. Poy migrated from Hong Kong to Canada for a university education, pursued a successful career in fashion design, and became the first Chinese and Asian woman to be appointed to the Canadian Senate, and was elected chancellor of the University of Toronto. Her sense of pride and involvement in the community shows in her facility with the intricacies of Canadian politics and immigration laws, and her familiarity with prominent Canadian Chinese leaders. This book grew out of Poy's PhD dissertation - completed late in her career - and is evidently the product of her strong engagement with her fellow travelers.

This sense of being "up close and personal" with the book's subject is both a strength and a limitation of this work. While carefully and clearly written, with a deep empathy for the human aspect of immigration history, Passage to Promise Land ultimately comes across as a fairly conventional narrative that does not delve as deeply as it could into the historiographical or theoretical issues involved in writing about gender, ethnicity, transnationalism, and oral histories. Poy is clear about her methodology and goals in the introductory chapter. She acknowledges that her pool of informants skews towards those who considered themselves successful and were willing to share their stories publicly, and nods towards the false dichotomy of victimisation versus agency - an important aspect in writing about women in patriarchal systems. However, the book does not engage in further conversation with much of the recent scholarship on Chinese migration and diaspora, of which there has been significant amounts in the past few decades. The work of historians Elizabeth Sinn and Glen Peterson, from 1999 and 1988 respectively, is cited briefly, but it would be interesting to know how their more recent and extensive publications intersect with Poy's findings. Similarly, it would be helpful to readers with an interest in overseas Chinese history to know how Poy situates her research in the context of other books in the field. These include more general histories by Adam McKeown, Philip Kuhn, Mae Ngai, and Madeline Hsu, for example, or classic works on Chinese women and oral histories by Judy Yung, Emily Honig, and Gail Hershatter. 
Poy highlights her interviewees' persistence in overcoming the marginalising effects of sexism, racism, and cultural dislocation. There are several poignant moments, such as some women's accounts of having their births in China reported by their Canadian Chinese fathers as the births of sons, so that their families could obtain birth certificates that could then be used by their brothers or sold to sons in other families for immigration to Canada. These women show great resilience and resourcefulness, and leave little doubt that they are a tiny sample of the many immigrants who struggled mightily to find a niche in their adopted country. At the same time, despite the author's acknowledgement of complexities in writing about her subjects' agency, her desire to underscore this element of their history leads to potential over-emphasis on women's oppression at the hands of patriarchy. For example, the phrase "victim of patriarchy," or some close variant thereof, recur on pages 19, 23, 69, 105, and 192 (twice in one page in the final instance).

Each woman's story is interspersed with Poy's analysis, which typically follows the arc of pushing past the abovementioned barriers, and concludes with the women expressing gratitude to Canada for the chance to build a better life for themselves and their families. These generalisations, while no doubt true and reflective of sincerely held feelings among the interviewees, also illustrate the difficulty of balancing self-narratives with scholarly argument. Poy avoids the pitfall of crowding out her interviewees' voices and emotions with her own analysis. However, she could also take a more complex interpretive stance. For example, when accounting for one interviewee's mother's reluctance to leave an abusive husband, Poy concludes that the mother was not a strong person, and that fear of losing face was likely her strongest motivating force (62-63). The reality, while impossible to know, may require at least a more complicated and nuanced assessment. Similarly, Poy accepts at face value another interviewee's statement that "she did not seem to mind gender discrimination" within her family, even though that state of affairs led this woman to have a forced abortion and a mental collapse that required constant tranquilisation for a time (105). Again, the author is careful not to overstep her bounds, and allows the story to speak for itself. But as the motif of overcoming patriarchal oppression repeats throughout the book, one wonders about the unspoken tensions, contradictions, and ambiguities that also populated these women's lives.

Poy's book contributes new and compelling information about the private worlds of Chinese Canadian immigrant women from World War II onwards. Crafting a history of a group that has traditionally been marginalised, on the move, and less likely to leave behind a conveniently accessible trove of written documentation is no mean feat. Poy's achievement here is showcasing the rich and dramatic lives of so-called ordinary women, whose voices carry the authority of experience and authenticity. Among other things, what Passage to Promise Land illustrates is the importance of using oral histories to show, and not 
just tell.

\section{Karen M. Teoh \\ Stonehill College \\ Larissa Sandy, Women and Sex Work in Cambodia: Blood, Sweat and Tears (New York: Routledge, 2014). 156 pp. \$145 Hardback.}

The value of this new book by Larissa Sandy lies in the important argument that sex workers should not be equated with trafficking victims, that many sex workers choose to engage in this form of labour (though from within a very limited range of options). Sandy "confronts and disrupts two predominant images of the "Cambodian prostitute:" that she is on the one hand a "ruined, destroyed and victimized woman" and that she is a "destroying body that threatens society" on the other - the victim and the vector. Instead she uses narratives from interviews with sex workers to introduce them as agents in their own lives.

The best chapters are five and six, which discuss the contemporary (1990s and 2000s) scene, utilizing the voices of the women interviewed. In chapter five, "Just Choices," Sandy examines the common claim by those interviewed that they chose sex work. While their options were very constrained, they nonetheless assert self-determination. She tells the women's stories as short vignettes, discussing at length debt bondage and distinguishing this from the notion of "trafficking." The women emphasize their responsibility to family and to repaying their debt to their parents especially their mothers. This "dutiful daughter" discourse will be familiar to those who have read other work on prostitution from the region, including Mills (1997), Muecke (1992) and Derks (2008).

Chapter six, "Core transmitter/sex slave," is a valuable discussion of the impact of the $100 \%$ Condom Use Program (CUP) on sex work in Cambodia from 1999-2008. Sandy argues that prostitution was essentially legalized and became much more highly regulated as female sex workers were framed as "perpetrators" and the source of the disease, while male clients were seen as "bridges" to other "innocent" women, their wives. Men were seen as the link between "bad" and "good" women and not responsible agents themselves. The law required brothel-based sex workers to report for health examinations, and established a sex worker registration and management system that heightened the ability of the police to extort money from brothel owners and to collude with the owners in monitoring a sex worker's debt and preventing her escape.

In 2008, the Cambodian government then passed a Human Trafficking Law, which Sandy argues effectively criminalized sex work and presented the women as "hapless victims." Sandy links this change to shifts in US government policy in the 2000s. The US passed legislation to fund a global fight against HIV/AIDS, but withdrew USAID support for organisations that advocated legalisation or decriminalisation of sex work. In the Trafficking Victims 